\title{
AUTOIMMUNITY IN CHILDHOOD EPILEPSY
}

\section{Paediatrics}

Sonali Verma*

Anju Aggarwal

MMA Faridi

\section{Gargi Rai}

Shukla Das
Department of Pediatrics, University College of Medical Sciences and Guru Teg Bahadur Hospital, Dilshad Garden, Delhi, India. *Corresponding Author

Department of Pediatrics, University College of Medical Sciences and Guru Teg Bahadur Hospital, Dilshad Garden, Delhi, India.

Department of Pediatrics, University College of Medical Sciences and Guru Teg Bahadur Hospital, Dilshad Garden, Delhi, India.

Department of Microbiology, University College of Medical Sciences and Guru Teg Bahadur Hospital, Dilshad Garden, Delhi, India

Department of Microbiology, University College of Medical Sciences and Guru Teg Bahadur Hospital, Dilshad Garden, Delhi, India.

Department of Biostatistics and informatics, University College of Medical Sciences and Guru Teg Bahadur Hospital, Dilshad Garden, Delhi, India.

\section{Rajeev Kumar} Malhotra

\section{ABSTRACT}

Objectives: To measure and compare the levels of anticardiolipin(aCL), anti- $\beta 2$-glycoprotein 1(a $\beta 2$ gp1) and antinuclear(ANA) antibodies in children with idiopathic epilepsy, epilepsy due to neurocysticercosis (NCC) and healthy controls and to find their correlation with clinical profile and recurrence of seizures.

Methodology: Study included 36 idiopathic epilepsy cases ( 2 to 12 years), 36 age and sex matched healthy controls and 36 children of epilepsy due to NCC. Neuroimaging and EEG were done in all cases of idiopathic epilepsy. Levels of aCL, a $32 \mathrm{gp} 1$ and ANA antibodies were measured using ELISA technique and compared among 3 groups.

Results: Idiopathic epilepsy cases were comparable to healthy controls based on age, anthropometry and hematological parameters. Among idiopathic epilepsy cases, mean a $32 \mathrm{gp} 1$ antibody levelswere $6.37 \pm 4.7 \mathrm{GPL} \mathrm{U} / \mathrm{mL}$ compared to $4.66 \pm 1.61 \mathrm{GPL} \mathrm{U} / \mathrm{ml}$ incontrols ( $\mathrm{p}=0.044$ ). a $32 \mathrm{gp} 1$ antibody positivity $(>12 \mathrm{GPL} \mathrm{U} / \mathrm{ml})$ was $11.1 \%$ in idiopathic epilepsy and none in controls $(\mathrm{p}=0.040)$. No significant difference was found between the levels of aCL and ANA antibody among idiopathic epilepsy cases and controls. Mean levels of aCL antibody in idiopathic epilepsy was 7.30 $\pm 4.16 \mathrm{GPL} \mathrm{U} / \mathrm{ml}$ as compared to $5.22 \pm 3.30 \mathrm{GPL} \mathrm{U} / \mathrm{ml}$ in NCCcases $(\mathrm{p}=0.022)$. aCL antibody was positive $(>10 \mathrm{GPL} \mathrm{U} / \mathrm{ml}) \quad \mathrm{in} 12(33.33 \%)$ idiopathic epilepsy cases versus $5(13.9 \%)$ in cases with NCC $(p=0.047)$. No significant difference was found between the levels of a 32 gp 1 and ANA antibody among idiopathic epilepsy cases and NCC cases( $\mathrm{p}>0.05)$. Antibody levels were statistically similar when compared based on age, sex, seizure type, recurrence $(\mathrm{p}>0.05)$.

Conclusion: Antibody levels were higher in idiopathic epilepsy group compared to healthy controls with statistical significance in anti- $\beta 2$ glycoprotein 1 antibody levels. Hence, autoimmunity has a role in idiopathic epilepsy.

\section{KEYWORDS}

childhood epilepsy; autoimmunity; antinuclear; anti- $\beta 2$-glycoprotein 1 ; anticardiolipin

\section{INTRODUCTION:}

Epilepsy is one of the most common neurological disorders contributing to significant morbidity in children. Structural, metabolic, genetic and acquired causes such as intracranial infections, trauma, have been identified; however the majority of epilepsies are known to have no detectable cause [1]. Such epilepsy is classified as idiopathic epilepsy. In recent years, autoimmunity has been hypothesized as potential cause of idiopathic epilepsy [2,3]. Studies have shown the role of autoantibodies as antiphospholipid antibodies (anticardiolipin, anti- $\beta 2$-glycoprotein 1 antibodies) and antinuclear antibodies in the pathogenesis of epilepsy $[4,5]$. Some studies have shown increased levels of antibodies in patients with NCC [6].

Anticardiolipin and anti- $\beta 2$-glycoprotein 1 antibodies recognize anionic phospholipid protein complexed with phospholipid [7]. Among them $\beta 2$-glycoprotein 1 appears to play an important pathogenic role. Antinuclear antibodies target histones and chromatin components of nucleus. Binding of antibodies to their targets promote loss of function or excessive function of some of the crucial components that regulate neuronal resting membrane potential or synaptic functions [8]. The main pathogenic mechanism by which antibodies cause seizures are direct immune mediated cellular damage or thrombotic events in the brain microcirculation. Some experimental studies described antiphospholipid antibody mediated disruption of neuronal function by direct action on nerve terminals [9].

Hence this study was conducted to measure the levels of anticardiolipin, anti- $\beta 2$-glycoprotein 1 and antinuclear antibodies in children with idiopathic epilepsy and to compare them with levels of these autoantibodies in healthy children and children with epilepsy due to NCC.

\section{MATERIALAND METHODS}

This study was a case control study in a tertiary care hospital in Delhi, India from November 2015 to April 2017. Sample size was calculated based on the study by Eriksson et al [5], where quantitative analysis of autoantibodies (anticardiolipin, anti- $\beta 2$-glycoprotein1, antinuclear antibodies) was carried out on 50 consecutive epilepsy patients 16 years or younger and 20 healthy controls. This study detected the prevalence of aCL antibodies in $44 \%$ cases and $10 \%$ controls $(\mathrm{p}=0.011)$ [5]. Taking $40 \%$ positivity in cases and $10 \%$ positivity in controls using formula - Inequality test for two proportions/ two proportion test, a sample size of 36 cases and 36 controls was required. Since no data is available about the autoantibodies in epilepsy due to neurocysticercosis, 36 cases of epilepsy due to neurocysticercosis were included in the research as another control group. The study was approved by ethical committee and informed consent was obtained from parents/guardian of the child.

Study included 36 cases of newly diagnosed idiopathic epilepsy belonging to age group 2 to 12 years. Diagnosis of epilepsy was made according to the definition of epilepsy which is defined as two unprovoked seizures occurring $>24$ hours apart or 1 unprovoked seizure and probability of further seizure similar to general recurrence risk (atleast 60\%) after two unprovoked seizures occurring over the next 10 years [10]. These children were enrolled within 15 days of diagnosis of epilepsy. None of the cases had been on any antiepileptic medication for more than 15 days. One group of controls consisted of 36 age and sex matched healthy children with no history of seizures in the past. Another group of controls included 36 children of newly diagnosed epilepsy due to neurocysticercosis. Epilepsy due to neurocysticercosis was defined as child presenting with seizures (partial or generalized) showing radiological features on 
neuroimaging as ring enhancing lesions 1 to 5 in number, $<2 \mathrm{~cm}$ in diameter, with regular margins with or without scolex and no evidence of tuberculosis.

Patients with congenital anomalies, developmental delay, meningitis, encephalitis, any epilepsy syndrome, patients with clinical signs of autoimmune diseases like SLE, Rheumatic diseases or patients on antiepileptic medications were excluded.

A baseline assessment included detailed clinical history and examination was carried out at the time of enrollment. We recorded anthropometric measurements for each child. Hemogram, liver function tests, electrolytes were done were carried out whenever required. Neuroimaging and EEG were carried out in all cases of epilepsy. Patients received antiepileptic treatment as per hospital protocol. Patients of neurocysticercois received Albendazole (a) $15 \mathrm{mg} / \mathrm{kg}$ for 28 days and steroids for 5 days. Patients were followed up for 4 months.

A sample of $3 \mathrm{ml}$ venous blood was withdrawn aseptically and serum was separated. Serum sample for antibody estimation was stored at $80^{\circ} \mathrm{C}$ till further use. Antibodies estimation was done by Calbiotech ELISA kits. Normal value of aCL antibody is $<10 \mathrm{GPL} \mathrm{U} / \mathrm{ml}$, a $\beta 2 \mathrm{gp} 1$ antibody is $<12 \mathrm{GPL} \mathrm{U} / \mathrm{ml}$ and ANA antibody is $<23 \mathrm{IU} / \mathrm{ml}$. Interobserver / intraobserver variation in kits was 5-7\%.

\section{Statistical Analysis:}

Data was recorded using Microsoft Excel and analysed using SPSS version 20.0. Characteristics of 2 groups (Idiopathic epilepsy and healthy controls) were analyzed and compared using Chi-square for qualitative and t-test for quantitative variables. Mann Whitney U test (non-parametric test) was applied whenever the data did not follow a normal distribution in the continuous variables. The levels of antibodies in children with epilepsy due to neurocysticercosis were compared similarly. Pearson's correlation coefficient was used for correlation.

\section{RESULTS}

The subjects $(n=36)$ enrolled in the study belonged to the age group of 2 to 12 years. The mean age in cases was $7.44 \pm 2.63$ years. Out of 36 cases enrolled, 20(55.6\%) were males and 16(44.4\%) were females. The first group of controls (healthy children, $n=36$ ) were age and sex matched. The second group of controls were 36 cases of epilepsy due to neurocysticercosis. The cases were similar to both group of controls on the basis of anthropometric and hematological parameters $(\mathrm{p}>0.05)$.

Table 1 shows the clinical characteristics of seizures in children with idiopathic epilepsy and epilepsy due to neurocysticercosis. Out of 36 cases of idiopathic epilepsy, $23(63.9 \%)$ cases had past history of seizues, but none of them had been on any antiepileptic medication previously. A total of $12(33.4 \%)$ cases of epilepsy due to neurocysticercosis, had past history of seizures. Recurrence of seizures on 4 months follow up period, occurred in $9(25 \%)$ cases of idiopathic epilepsy and $4(11.1 \%)$. Dose escalation or change of anticonvulsant was done on recurrence of seizures.

Table 1: Clinical characteristics of seizures

\begin{tabular}{|l|l|l|}
\hline $\begin{array}{l}\text { Clinical } \\
\text { characteristics }\end{array}$ & $\begin{array}{l}\text { Idiopathic epilepsy } \\
\text { group n(\%) }\end{array}$ & $\begin{array}{l}\text { NCC group } \\
\text { n(\%) }\end{array}$ \\
\hline Type of seizure & & \\
\hline$-\quad$ GTCS & $26(72.2 \%)$ & $4(11.12 \%)$ \\
\hline$-\quad$ Partial & $10(27.8 \%)$ & $32(88.9 \%)$ \\
\hline \begin{tabular}{r|r|} 
Past history of seizure \\
Yes
\end{tabular} & $23(63.9 \%)$ & $12(33.4 \%)$ \\
\hline$-\quad$ No & $13(36.1 \%)$ & $24(66.6 \%)$ \\
\hline $\begin{array}{l}\text { Family history of } \\
\text { seizure Yes }\end{array}$ & & \\
\hline- & $6(16.7 \%)$ & $2(5.5 \%)$ \\
\hline- & $30(83.3 \%)$ & $34(94.5 \%)$ \\
\hline $\begin{array}{l}\text { Recurrence on follow- } \\
\text { up at 4 months }\end{array}$ & & \\
\hline- & $9(25 \%)$ & $4(11.12 \%)$ \\
\hline- & $27(75 \%)$ & $32(88.9 \%)$ \\
\hline
\end{tabular}

Neuroimaging was carried out in all cases of idiopathic epilepsy and epilepsy due to neurocysticercosis. Neuroimaging findings were normal in all cases of idiopathic epilepsy. Out of 36 cases of epilepsy due to neurocysticercosis. Multiple cysticerci were seen in 2 cases and remaining had single ring enhancing lesion on neuroimaging.

Table 2 depicts the mean levels of autoantibodies in idiopathic epilepsy cases in comparison with healthy controls and neurocysticercosis group. Levels of serum anti- $\beta 2$-glycoprotein 1 antibody in idiopathic epilepsy group was significantly higher $(6.31 \pm 4.7 \mathrm{GPL} \mathrm{U} / \mathrm{ml})$ than healthy controls $(4.66 \pm 1.61 \mathrm{GPL} \mathrm{U} / \mathrm{ml})(\mathrm{p}=0.044$ using parametric ttest). Levels of anticardiolipin antibody were significantly more in idiopathic epilepsy compared to NCC group (7.30 $\pm 4.16 \mathrm{GPL} \mathrm{U} / \mathrm{ml}$ and $5.41 \pm 3.21 \mathrm{GPL} U / \mathrm{ml}, \mathrm{p}=0.022$ by parametric t-test). There was no significant difference in antinuclear antibody levels in 3 groups $(\mathrm{p}>0.05)$

Table 2: Mean levels of autoantibodies in idiopathic epilepsy group versus NCC group and health controls

\begin{tabular}{|l|l|l|l|l|l|l|}
\hline $\begin{array}{l}\text { Mean } \\
\text { values }\end{array}$ & $\begin{array}{l}\text { Idiopathi } \\
\text { c epilepsy } \\
\text { group } \\
\text { (n=36) }\end{array}$ & $\begin{array}{l}\text { Healthy- } \\
\text { control } \\
\text { s } \\
(\mathbf{n = 3 6})\end{array}$ & $\begin{array}{l}\text { pdiopathic } \\
\text { value } \\
* \\
\text { epilepsy } \\
\text { group } \\
\text { (n=36) }\end{array}$ & $\begin{array}{l}\text { NCC } \\
\text { group } \\
\text { (n=36) }\end{array}$ & $\begin{array}{l}\text { p- } \\
\text { value } \\
*\end{array}$ \\
\hline $\begin{array}{l}\text { Serum aCL } \\
\text { levels } \\
\text { (GPL U/ml) }\end{array}$ & $7.30 \pm 4.16$ & $6.92 \pm 3$. & 0.672 & $7.30 \pm 4.16$ & $\begin{array}{l}5.22 \pm 3 \\
.30\end{array}$ & $\begin{array}{l}0.022 \\
* * *\end{array}$ \\
\hline $\begin{array}{l}\text { Serum a2 } \\
\text { glycoprotein } \\
1 \\
(\text { GPL U/ml) }\end{array}$ & $6.37 \pm 4.7$ & $\begin{array}{l}4.66 \pm 1 . \\
61\end{array}$ & $\begin{array}{l}0.044 \\
* *\end{array}$ & $6.37 \pm 4.7$ & $\begin{array}{l}5.41 \pm 3 \\
.21\end{array}$ & 0.314 \\
\hline $\begin{array}{l}\text { Serum ANA } \\
\text { levels } \\
(\text { IU/ml) }\end{array}$ & $8.31 \pm 3.48$ & $8.55 \pm 1$. & 0.719 & $8.31 \pm 3.48$ & $\begin{array}{l}7.89 \pm 4 \\
.08\end{array}$ & 0.640 \\
\hline
\end{tabular}

*Using T-test $* * p<0.05$

Table 3 depicts serum autoantibodies positivity in idiopathic epilepsy group is compared with positivity in healthy controls and NCC group. Out of 36 cases of idiopathic epilepsy, $4(11.1 \%)$ were positive for anti$\beta 2$-glycoprotein 1 antibody versus $0 \%$ positivity seen in healthy controls $(p=0.040)$. Positivity for anticardiolipin antibody in idiopathic epilepsy cases was seen in $12(33.3 \%)$ cases and $5(13.9 \%)$ cases of NCC group $(\mathrm{p}=0.047)$.

Table 3: Autoantibody positivity in idiopathic epilepsy group versus NCC group and health controls

\begin{tabular}{|c|c|c|c|c|c|c|}
\hline Mean values & $\begin{array}{l}\text { Idiopathi } \\
\text { c epilepsy } \\
\text { group } \\
(\mathrm{n}=36)\end{array}$ & $\begin{array}{l}\text { Healthy } \\
\text { controls } \\
(n=36)\end{array}$ & \begin{tabular}{|l|}
$p-$ \\
value \\
$*$
\end{tabular} & $\begin{array}{l}\text { Idiopathi } \\
\text { c epilepsy } \\
\text { group } \\
(\mathbf{n}=\mathbf{3 6})\end{array}$ & $\begin{array}{l}\text { NCC } \\
\text { group } \\
(n=36)\end{array}$ & $\begin{array}{l}\text { p- } \\
\text { valu } \\
\mathrm{e}^{*}\end{array}$ \\
\hline $\begin{array}{l}\text { Serum aCL } \\
\text { levels } \\
\text { (GPL U/ml) } \\
>10 \text { (positive) }\end{array}$ & $\begin{array}{l}12 \\
(33.33 \%)\end{array}$ & $\begin{array}{l}7 \\
(19.44 \% \\
)\end{array}$ & 0.142 & $\begin{array}{l}12 \\
(33.33 \%)\end{array}$ & $\begin{array}{l}5 \\
(13.9 \%)\end{array}$ & $\begin{array}{l}0.04 \\
7 * *\end{array}$ \\
\hline $\begin{array}{l}\text { Serum a2 } \\
\text { glycoprotein } \\
1 \\
(\mathrm{GPL} \mathrm{U} / \mathrm{ml}) \\
>12 \text { (positive) }\end{array}$ & $4(11.1 \%)$ & $0(0 \%)$ & $\begin{array}{l}0.040 \\
* *\end{array}$ & $4(11.1 \%)$ & $2(5.6 \%)$ & $\begin{array}{l}0.33 \\
7\end{array}$ \\
\hline $\begin{array}{l}\text { Serum ANA } \\
\text { levels } \\
(\mathrm{IU} / \mathrm{ml}) \\
>23 \text { (positive) }\end{array}$ & $1(2.8 \%)$ & $0(0 \%)$ & 0.314 & $1(2.8 \%)$ & $1(2.8 \%)$ & $\begin{array}{l}0.75 \\
4\end{array}$ \\
\hline
\end{tabular}

*Using Pearson chi-square test

Table 4 depicts the correlation of mean serum levels of autoantibodies with the clinical characteristics of idiopathic epilepsy group. It was found that serum levels of aCL, anti- $\beta 2$-glycoprotein 1 and antinuclear antibodies did not vary when compared on the basis of age $(<5$ or $\geq 5$ years), sex of the patient or type of seizures (generalized or partial seizure) $(\mathrm{p}>0.05)$.

Table 4: Comparison of mean serum levels of autoantibodies with clinical characteristics of IE group

\begin{tabular}{|c|c|c|c|c|c|}
\hline Parameters & $\mathrm{aCL}$ & a2gp1 & ANA & & \\
\hline & Mean & p-value & Mean & \begin{tabular}{l|l} 
p-value & Mean
\end{tabular} & p-value \\
\hline
\end{tabular}




\begin{tabular}{|c|c|c|c|c|c|c|}
\hline Age & & & & & & \\
\hline$<5(\mathrm{n}=5)$ & $8.49 \pm 5.07$ & 0.478 & $7.10 \pm 4.02$ & 0.478 & $\begin{array}{l}9.06 \pm \\
2.22\end{array}$ & 0.262 \\
\hline $5(n=31)$ & $7.10 \pm 4.06$ & & $6.29 \pm 4.87$ & & \begin{tabular}{|l|}
$8.19 \pm$ \\
3.65
\end{tabular} & \\
\hline Sex & & & & & & \\
\hline Male $(\mathrm{n}=20)$ & $6.46 \pm 4.05$ & 0.203 & $6.85 \pm 5.93$ & 0.504 & \begin{tabular}{|l|}
$8.14 \pm$ \\
4.21
\end{tabular} & 0.226 \\
\hline $\begin{array}{l}\text { Female } \\
(\mathrm{n}=16)\end{array}$ & $8.34 \pm 4.17$ & & $5.78 \pm 2.59$ & & \begin{tabular}{|l|}
$8.53 \pm$ \\
2.39
\end{tabular} & \\
\hline $\begin{array}{l}\text { Type of } \\
\text { seizure }\end{array}$ & & & & & & \\
\hline $\begin{array}{l}\text { GTCS } \\
(\mathrm{n}=26)\end{array}$ & $7.33 \pm 4.14$ & 0.972 & $6.75 \pm 5.20$ & 0.751 & \begin{tabular}{|l|}
$7.97 \pm$ \\
2.35
\end{tabular} & 0.972 \\
\hline $\begin{array}{l}\text { Partial } \\
(\mathrm{n}=10)\end{array}$ & $7.21 \pm 4.42$ & & $5.40 \pm 3.18$ & & $\begin{array}{l}9.20 \pm \\
5.52\end{array}$ & \\
\hline
\end{tabular}

*Using Mann-Whitney U test

The comparison of serum levels of autoantibodies with clinical characteristics of neurocysticercosis group revealed no correlation on the basis of clinical characteristics of patients.

\section{DISCUSSION}

This case control study determined serum levels of anticardiolipin (aCL), anti $\beta 2$-glycoprotein 1 and antinuclear antibodies were studied in 36 children with idiopathic epilepsy, 36 age and sex matched healthy controls without epilepsy and in 36 children with epilepsy due to neurocysticercosis.

Serum levels of anticardiolipin antibodies (aCL) were 7.30 $\pm 4.16 \mathrm{GPL}$ $\mathrm{U} / \mathrm{mL}$ ( range $1.75-15.88$ ) in children of idiopathic epilepsy and 6.92 $\pm 3.28 \mathrm{GPL} \mathrm{U} / \mathrm{mL}$ (range 2.27-12.76) in controls. Though the mean levels were higher in children with idiopathic epilepsy, the difference was not statistically significant ( $\mathrm{p}=0.627$, Table 2 ). Omnia et al (11), had IgG aCL antibodies $11.32 \pm 6.30 \mathrm{GPL} \mathrm{U} / \mathrm{mL}$ among cases and 5.25 $\pm 1.90 \mathrm{GPL} \mathrm{U} / \mathrm{mL}$ in controls $(\mathrm{p}<0.001)$, hence a significantly higher level in patients with epilepsy. They included children 2-16 years of age at different stages of epilepsy treatment and only 10 were newly diagnosed cases. Rest of the studies in children have not mentioned about the mean levels of these antibodies [5,12]. Levels of $>10 \mathrm{GPL}$ $\mathrm{U} / \mathrm{mL}$ was considered as positive in the present study as in most of the previous studies. The children with idiopathic epilepsy had higher positivity, $33.34 \%$ aCL antibodies; as compared to $19.4 \%$ among controls ( $\mathrm{p}=0.142$, Table 3 ). Eriksson et al [5] found $44 \%$ positivity in epilepsy cases and $10 \%$ in controls $(\mathrm{p}=0.011)$.

Variation in levels of antibodies and positivity can be explained by difference in patient profile. None of the previous studies has estimated levels in Indian settings. Our study included children of age 2 to 12 years; while other studies included a mixed group of population including adolescents and children. Study conducted by Omnia et al (11), included patients with idiopathic epilepsy as well as cryptogenic epilepsy. Eriksson et al (5) in their study included patients with localization related idiopathic epilepsy/symptomatic epilepsy, generalized idiopathic epilepsy/ symptomatic epilepsy and mixed epilepsy. Present study included cases of idiopathic epilepsy only.

Mean levels of anti- $\beta 2$-glycoprotein 1 antibody in children with idiopathic epilepsy was $6.37 \pm 4.70 \mathrm{U} / \mathrm{ml}$ (range-2.27-24.84) and 4.66 $\pm 1.61 \mathrm{U} / \mathrm{ml}$ (range- 2.41-9.45) in controls ( $\mathrm{p}=0.044 \mathrm{bTable} 2)$. This result was in contrast to study by Omnia et al which revealed no significant difference in the value of anti- $\beta 2$-glycoprotein 1 antibody IgG levels of $7.21 \pm 6.61 \mathrm{U} / \mathrm{ml}$ in epilepsy cases compared to $5.51 \pm$ $1.91 \mathrm{U} / \mathrm{ml}$ in controls $(\mathrm{p}>0.05)$. In our study, levels of anti $\beta 2$ glycoprotein 1 antibody $>12 \mathrm{U} / \mathrm{ml}$ were considered positive. Among 36 cases of idiopathic epilepsy, 4 (11.1\%) were positive for anti $\beta 2$ glycoprotein 1 , whereas none was positive among controls (Table 9). It has been postulated that antiphospholipid antibodies (anticardiolipin + anti- $\beta 2$-glycoprotein 1) have a role in pathogenesis of epilepsy in genetically predisposed individuals. These antibodies are known to cause thrombosis mediated ischaemic events in the brain tissue. Antibodies to endothelium frequently coexist with antiphospholipid antibodies and may induce apoptosis within CNS. Meroni et al (12) demonstrated that human brain microvascular endothelial cells bind higher amounts of $\beta 2$-glycoprotein 1 and thus is activated by anti $\beta 2$ glycoprotein 1 antibodies. It is seen that the mechanism of causation of seizures by anti- $\beta 2$-glycoprotein 1 antibodies is similar to that of anticardiolipin antibodies. These antibodies cause seizures by means of microinfarcts formation secondary to ischaemic events or by direct immune mediated destruction of endothelial or neuronal cells. $\beta 2$ glycoprotein 1 is specific for thrombosis related events. $\beta 2-$ glycoprotein 1 leads to a procoagulant state causing priming of endothelium thus leading to leucocyte adhesion and thrombosis. It has been shown that purified IgG from a patient with anticardiolipin or anti $\beta 2$-glycoprotein 1 will induce depolarisation of synaptoneurosomes, causing excitatory manifestations such epilepsy or chorea [11].

Mean levels of antinuclear antibody in children with idiopathic epilepsy were $8.31 \pm 3.48 \mathrm{U} / \mathrm{ml}$ (range -3.48-24.95) compared to 8.55 $\pm 1.83 \mathrm{U} / \mathrm{ml}$ (range $-5.71-14.12$ ) in healthy controls (Table 2, $\mathrm{p}=0.719$ ). Levels $>23 \mathrm{IU} / \mathrm{ml}$ was taken as positive in our study as per manufacturers instruction. The qualitative comparison between 2 groups revealed $2.8 \%$ positivity in children with idiopathic epilepsy and $0 \%$ positivity in controls (Table 3 ). Insignificant difference in the levels of antinuclear antibody between cases and controls could be due to non-specific nature of this antibody. This antibody is associated with many autoimmune disorders and is sometimes normally present in the serum. Verrot et al. in 1991 were first to demonstrate antinuclear antibody in patients of focal epilepsy who did not have SLE. Constantin et al postulated that the prevalence of antinuclear antibody titres in general population is 4-22\% depending on the titres of antinuclear antibody levels estimated [9]. ANA is more common in patients with autoimmune disease such as SLE but prevalence of SLE and other autoimmune diseases in patients of epilepsy are unknown. Antiepileptics such as phenytoin and carbamazepine have been implicated as activators of production of antinuclear antibodies and drug induced SLE. Valproate has been reported to cause induction of antibody formation. Varying pattern of antiepileptic use may partly explain the pattern of antibody positivity. This was taken care of in our study as we included only newly diagnosed epilepsy. the serum levels of aCL, anti- $\beta 2$ glycoprotein 1 and antinuclear antibodies didn't vary significantly in cases of generalized seizures when compared with cases of partial seizures. Previous studies had by Peltola et al [13], Verrot et al [14] where they concluded that antibody levels were higher in cases of localization related epilepsy though no mean levels were mentioned.

Mean serum levels of aCL antibody in Neurocysticercosis (NCC) cases was found to be $5.22 \pm 3.30 \mathrm{GPL} \mathrm{U} / \mathrm{ml}$ (range -1.35-12.87) as compared to $7.30 \pm 4.16 \mathrm{GPL} \mathrm{U} / \mathrm{ml}$ (range - $1.75-15.88$ ) in idiopathic epilepsy cases $(\mathrm{p}=0.022$ by $\mathrm{t}$-test, $\mathrm{p}=0.029$ by non parametric tests, Table 2), hence a significantly lower levels in children with epilepsy due to neurocysticercosis as compared to those with idiopathic epilepsy. Levels of anti- $\beta 2$-glycoprotein 1 antibody and antinuclear antibody were not significantly different in two groups $(\mathrm{p}>0.05$, Table 2). Positivity of anticardiolipin antibody was significantly higher in idiopathic epilepsy cases (33.33\%) as compared to $13.9 \%$ in epilepsy due to NCC ( $\mathrm{p}=0.047$, Table 3$)$. Positivity of anti- $\beta 2$-glycoprotein 1 antibody was $11.1 \%$ in idiopathic group as compared $5.6 \%$ in NCC group $(\mathrm{p}=0.337$, Table 3$)$. The positivity for antinuclear antibody was $2.8 \%$ in idiopathic group which was same as NCC group (positivity seen in $2.8 \%$ case, Table 3 ).

Hence in the present study serum levels of anti- $\beta 2$-glycoprotein 1 antibody was found to be significantly higher among children with idiopathic epilepsy when compared to age and sex matched healthy children. Levels of anticardiolipin and antinuclear antibody were higher in children with idiopathic epilepsy though the difference was not statistically significant. Children with idiopathic epilepsy had significantly higher anticardiolpin antibody compared to children who developed epilepsy due to neurocysticercosis. Further studies are required to elucidate the role of autoimmunity in causation of seizures in idiopathic epilepsy.

\section{REFERENCES:}

1. Berg AT, Berkovic SF, Brodie MJ, ET al. Revised terminology and concepts of organization of seizures and epilepsies: report of the ILAE Commission on organization of seizures and epilepsies: report of the ILAE Co
Classification and Terminology, 2005-2009. Epilepsia 2010;51:676-685.

2. Palace J, Lang B. Epilepsy: An autoimmune disease? J Neuro Neurosurg Psych 2000;69:711-714

Bauer J, Bien CG, Encephalitis and epilepsy. Semin Immunopathol 2009;31:537-544

4. Cimaz R, Romeo A, Scarano A, Avcin T, Viri M, Veggiotti P, et al. Prevalence of anticardiolipin, anti-beta2 glycoprotein I, and anti-prothrombin antibodies in young patients with epilepsy. Epilepsia 2002;43(1):52-9.

5. Eriksson K, Peltola J, Keränen T, Haapala AM, Koivikko M. High prevalence of antiphospholipid antibodies in children with epilepsy: a controlled study of 50 cases. Epilepsy Res 2001;46:129-37.

6. Wasu VS, Durga Padmaja G. Antiphospholipid antibodies in epilepsy with particular 
reference to neurocysticercosis in children. J Pharm Biomed Sci 2015;5:178-181.

7. McNeil HP, Simpson RJ, Chesterman CN, Krilis SA. Anti-phospholipid antibodies are directed against a complex antigen that includes a lipid-binding inhibitor of coagulation: beta 2-glycoprotein I (apolipoprotein H). Proc Natl Acad Sci USA 1990;87:4120-4.

8. Vincent A, Lang B, Kleopa KA. Autoimmune channelopathies and related neurological disorders. Neuron 2006;52:123-38.

9. Constantin T, Kálovics T, Ponyi A, Nagy E, Sallai K, Szabó L, et al. Prevalence of antiphospholipid and antinuclear antibodies in children with epilepsy. Med Sci Monit 2009;15:164-9.

10. Epilepsy Fact sheet. WHO. February 2016. Available from: https://communit ymedicine4asses.wordpress.com/2016/02/1 1/who-updates-fact-sheet-on-epilepsy-10February-2016/. Accessed on 20th April 2017.

11. El-Rasheidy Omnia, El-Fedawy SF, Tomoum HY, El-Zeany MB. Antiphospholipid antibodies in children and adolescents with epilepsy. Egypt J Pediatr Allergy Immunol antibodies in children and adolescents with epilepsy. Egypt J Pediatr Allergy Immunol

12. Meroni PL, Raschi E, Camera M, et al. Endothelial activation by aPL: a potential pathogenetic mechanism for the clinical manifestation of the syndrome. J Autoimmun 2000;15:237-40

13. Peltola JT, Haapala A, Isojärvi JI, Auvinen A, Palmio J, Latvala K, et al. Antiphospholipid and antinuclear antibodies in patients with epilepsy or new-onset seizure disorders. Am J Med 2000;109:712-717.

14. Verrot D, San-Marco M, Dravet C, Genton P, Disdier P, Bolla G, et al. Prevalence and signification of antinuclear and anticardiolipin antibodies in patients with epilepsy. Am J Med 1997:103:33-7. 